\title{
INSTITUTE NOTES
}

The following lectures have been arranged for the 1949-50 Session:

University Hall, ${ }_{4}$ Gordon Square, W.C.I, at 5.15 p.m.

1949

October I4 Scope and Aims of "Synoptic" Philosophy

October 21 Russell's Theory of the External World

October 28 Russell's Neutral Monism

November 4 Neutral Monism and the Philosophy of Nature

A course of four lectures by Prof. H. H. Price on Synoptic Philosophy (The Phitosophy of Nature).

November II Scientific Concepts and Synthetic Philosophy

S. E. Toulmin, M.A.

November 18 "Everything"

H. L. A. Hart, M.A.

1950

January 27 The Philosophy of Human Nature and the Science of Human Nature

February 3 Ways of Knowing and Kinds of Knowledge

February Io Morality: Tradition and Reason

February I7 Truths of Reflection and Imagination

A course of four lectures by Karl Britton, M.A., on The Philosophy of Human Nature.

University College, (Anatomy Theatre), Gower Street, W.C.I, at 7.30 p.m.

1949

November 16 Hume and Kant and Their Attitude to $\}$ P. F. Strawson, Metaphysics M.A.

$195^{\circ}$

March

22 The Gates of the Future

Prof. J. W. Harvey

\section{OBJECTS OF THE INSTITUTE}

The Royal Institute of Philosophy exists to bring leading exponents of various branches of Philosophy into direct contact with the general public, with the purpose of satisfying a need felt by many men and women in every walk of life for greater clearness and comprehensiveness of vision in human affairs.

Further information and forms of application for membership may be had on application to the Director of Studies at University Fall, 14 Gordon Square, London, W.C.1.

\section{[Suggested]}

\section{FORM OF BEQUEST}

I bequeath to THE ROYAL INSTITUTE OF PHILOSOPHY the sum of $\ldots \ldots \ldots \ldots \ldots \ldots$ free of duty to be applied to the purposes of that Institute, and I declare that the receipt of the Honorary Secretary, or other proper officer for the time being of that Institute, shall be sufficient discharge for the same. 